The University of San Francisco

USF Scholarship: a digital repository @ Gleeson Library |

Geschke Center

Business Analytics and Information Systems

School of Management

2008

\title{
Manipulatives in the History of Teaching: Fast Forward to AutOMathic Blocks for the Blind
}

Arthur Karshmer

University of San Francisco, akarshmer@usfca.edu

Follow this and additional works at: http://repository.usfca.edu/at

\section{Recommended Citation}

Karshmer, Arthur, "Manipulatives in the History of Teaching: Fast Forward to AutOMathic Blocks for the Blind" (2008). Business Analytics and Information Systems. Paper 17.

http://repository.usfca.edu/at/17 Gleeson Library | Geschke Center. It has been accepted for inclusion in Business Analytics and Information Systems by an authorized administrator of USF Scholarship: a digital repository @ Gleeson Library | Geschke Center. For more information, please contact repository@usfca.edu. 


\title{
Manipulatives in the History of Teaching: Fast Forward to AutOMathic Blocks for the Blind ${ }^{1}$
}

\author{
Arthur I. Karshmer and Daryoush Farsi \\ University of San Francisco \\ The Universal Math Access Lab \\ 281 Masonic \\ San Francisco, CA 94117 USA \\ \{akarshmer,farsi\}@usfca.edu
}

\begin{abstract}
The use of manipulative objects in the teaching of younger children has been a well know and accepted educational practice for over 200 years. The use of manipulative blocks have been valuable in the teaching of subjects such as the alphabet, linear and multidimensional measurements and early mathematics to name a few. In the current work, we present a brief overview of the traditional use of these tools as a basis for the discussion of the the AutOMathic Blocks system - a systems that integrates the physical manipulative object with a computer to deliver personal math instruction to young students with visual impairments.
\end{abstract}

\section{Introduction}

The English philosopher and educator, John Locke, took note of the use of blocks in education in his book Some Thoughts on Education [1]. In this work he cites a number of toys used in education, primarily the uses of blocks to teach the alphabet in $17^{\text {th }}$ century England. The $18^{\text {th }}$ century Anglo-Irish educational theorists, Maria Edgeworth and Richard Lovell Edgeworth [2] were proponents of the use of toys in the learning process. In the early $18^{\text {th }}$ century Fredrich Froebel, the father of the German Kindergarten movement advocated the use of toys and related activities which he called "Gifts" and "Occupations," in his 1891 book, [3] "The Education of Man." From their humble beginnings, the use of manipulative objects in teaching has become an important part of the education of younger children. There is a website [4] which lists almost 200 examples of the use of manipulatives in education.

In an interesting biography of Louis Braille, titled Out of the Darkness: The story of Louis Braille, [5], it is noted that Braille himself used manipulative blocks to teach the Braille alphabet. In a recent review paper, Susan Osterhaus [6] from the Texas School for the Blind and Visually Impaired has an entire section dedicated to "Tools and Strategies for Teaching Math to Students that are Blind or Visually Impaired." The use and efficacy of this approach to learning math by the blind, is echoed by John Gardner [7], a well-known and respected developer of technologies for the blind. In

\footnotetext{
${ }^{1}$ The current work has been funded by the Jesuit Foundation at the University of San Francisco
} 
the more general case of manipulatives and math, Marsh [8] describes methods of teaching visually impaired students using blocks to improve their understanding of the abstract symbolic language of Math.

While there are several block based math learning systems available for the blind, they all lack an important element - interactive tutoring. Products from Uncle Goose [9], Independent Living [10] (see figure 1 below) and other similar block oriented math learning tools do indeed give the blind student the ability to substitute touch or vision in the learning process. But they are only effective in cooperation with a teacher or parent. For a broad overview of the use of manipulatives in special education (see [10]).
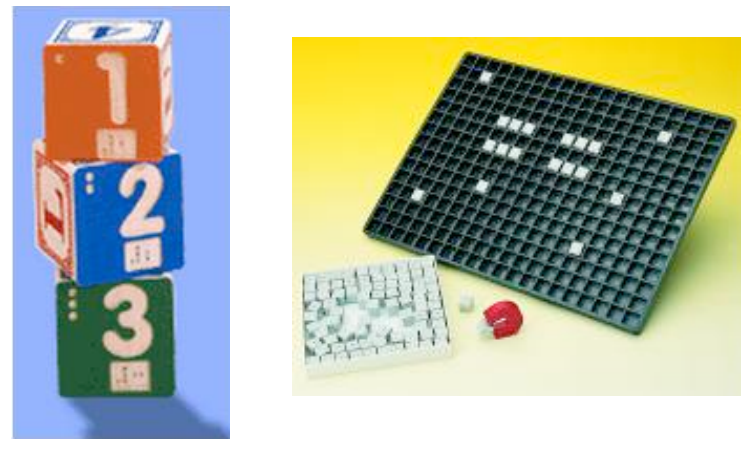

Figure 1. Braille Math Blocks from Uncle Goose \& Independent Living

\section{The Failure of Manipulates in teaching the Blind.}

The blocks depicted above are two examples of using manipulative objects, which include Braille labels, in the teaching process for young blind students. Both of these products allow the student to layout, read and manipulate arithmetic problems. While both are valid teaching tools, they lack real-time supervision and tutoring tools in the absence of teacher or parent.

What these tools lack is "intelligence." The traditional source of intelligence in this learning process has been the student's teacher or parent. But here is where the problem lies.

\section{Manipulative Learning with Computer-Assisted Intelligence.}

Blocks, being what they are, lack any intelligence. While there will be a change in this situation in the near future, the availability of such blocks will not be ready or inexpensive enough to be used in assistive technologies in the near future. Every block would need both intelligence in the form of an imbedded chip and communications equipment to exchange information with other blocks in the learning 
system. So, in the meantime, we need to centralize the intelligence in a traditional or special purpose personal computer. The interesting aspect of using the traditional computer approach is that it will yield knowledge and special algorithms that will be of use in the future intelligent block approach.

\section{Enter the AutOMathic Blocks System}

A prototype system that uses manipulative block, encoded in Braille, and simple offthe-shelf technology to add help and tutoring to the blind student has been built at The Universal Math Access Lab at the University of San Francisco (see figure 2 below).

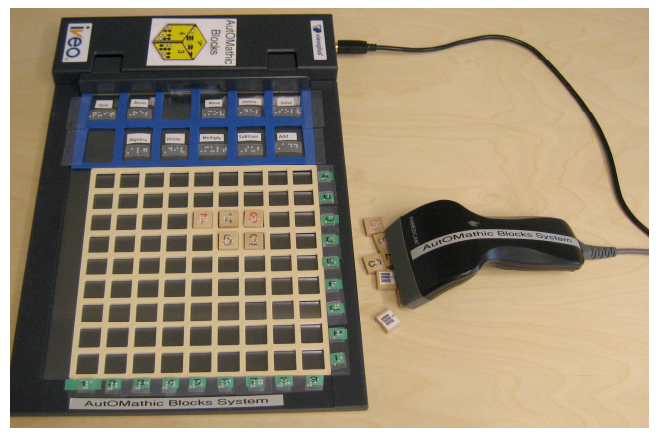

Figure 2. The AutOMathic Blocks Prototype

The system currently employs 1 inch x 1 inch $(2.5 \times 2.5 \mathrm{~cm})$ blocks that carry passive information in three different forms.

1. The numeric identifier of the block in large print. This information is to be used by the sighted parent or teacher to follow the activities of the student.

2. A Braille label caring the same information as is printed on the block.

3. On the reverse side of the block there is a standard barcode label carrying the same information as on the front of the block.

The remaining equipment used in the system is comprised of

1. Any inexpensive laptop or desktop computer containing a USB interface.

2. An inexpensive barcode scanner for sending block information to the computer.

3. A touchpad device that has two functions.

a. A convenient workspace for the student.

b. A device that transfers information to the computer concerning the relative placement of all blocks in use.

4. A simple storage bin for the blocks 


\section{Current System Status}

The AutOMathic Blocks system is currently functional. It allows the student, without guidance from teacher or parent, to setup and edit math problems on the workspace, and then proceed to solve them with interactive help from the computer. The system offers the blind student total freedom to learn where and when they want. The system is completely designed for the student and autonomous learning.

The prototype AutOMathic Blocks system has software and hardware to interact with the student through all phases of the learning process. Currently, the system can handle any type of addition problem, including the concept of carry from previous columns. Simple subtraction, multiplication and division are functional, but substantial software must be written to fully implement these functions. Finally, simple algebra will be added to the system. Tutoring modules are now rudimentary, but modules will be further implemented by a multinational group working with our lab.

We feel that the math and basic algebra facilities are only the beginning of the potential of our system. There seem to be numerous other learning environments for the blind, which can be served by the system. For example, spelling, grammar, simple graphing and others are certainly good candidates.

\section{References}

1. Locke, J., John, J.A.S., Some Thoughts on Education, Oliver and Boyd, (1836)

2. HighBeam Encyclopedia, http://www.encyclopedia.com/doc/1E1-EdgewortR.html

3. Froebel, F.: The Education of Man, International Education Series, D Appleton and Company, New York (1891)

4. Education Curriculum, http://w2.byuh.edu/library/curriculum/MathMan/MathMan.htm

5. Freedman, R., Out of the Darkness: The Story of Louis Braille, Houghton-Mifflin, (1997)

6. Osterhaus, S., Tools and Strategies for Teaching Math to Students that are Blind or Visually Impaired, TSVBI, http:/www.tsbvi.edu/math/alberta-022605.htm

7. Gardner, J.A., Proceedings of the 1993 International Conference on Technology and Persons with Disabilities, Los Angeles, CA, March 1993.

8. Marsh, L.G., Learning Mathematics with Virtual Manipulatives, CITEd Research Center, http: www.cited.org/index.aspx?page_id=151

9. Uncle Goose, http://www.unclegoose.com/BlocksBrailleMath.html

10. Independent Living, http://www.independentliving.com/departments.asp?dept=77 